\title{
POTENSI DAN KESESUAIAN LAHAN BUDIDAYA RUMPUT LAUT (Kappaphycus alvarezii) DI SEKITAR PERAIRAN KABUPATEN WAKATOBI PROVINSI SULAWESI TENGGARA
}

\section{POTENTIAL AND SUITABILITY OF LAND SEAWEED FARMING (Kappaphycus alvarezii) WATER AROUND THE DISTRICT WAKATOBI SOUTHEAST SULAWESI}

\author{
Nur Ansari Rangka dan Mudian Paena \\ Balai Riset Perikanan Budidaya Air Payau (BRPBAP) \\ J1. Makmur Daeng Sitakkan No. 129, Maros, Sulawesi Selatan, 90512 Telp. 0411-371544 \\ mudianpaena@yahoo.co.id
}

\begin{abstract}
Ragulasi government of commodities in the field of aquaculture developed into a major trigger of the mushrooming development of seaweed farming. (Kappaphycus alvarezii) in most coastal areas in Indonesia, not least in district Wakatobi Southeast Sulawesi. In development, the local government in this case the relevant agencies do not yet have data on potential and suitability of the land to be used as a reference in determining the development strategy. Based on this research has been done to calculate the potential and aimed to determine the suitability of land for seaweed cultivation in the district of Wakatobi. The study was conducted with the direct survey method to extract the characteristics of the study sites for hydro-oceanographic dynamics which is closely linked with the growth of seaweed. Data were tabulated and the field measurement results were analyzed descriptively, whereas spatial analysis for thematic map creation and distribution of the potential suitability of land is done by applying the technology of geographic information systems (GIS) utilizing software Arc-View 3.3. The results showed that the distribution characteristics of hydro-dynamics-osenaografi around Wakatobi waters are bersubstrat sand, coral sand and coral; flow rate between 0.011 to $0.07 \mathrm{~m} / \mathrm{sec}$; brightness from 2.5 to 15 meters; depth of 2.5 to 13.7 meters; temperature of 29.42 to $30.2^{\circ} \mathrm{C}$; $\mathrm{pH} 7.58$ to 8.23 ; salinity 34.95 to $36.88 \mathrm{ppt}$; okesigen dissolved from 6.06 to $6.25 \mathrm{~m} / \mathrm{L}$; total organic matter (BOT) from 35.52 to $42.6 \mathrm{mg} / \mathrm{L}$; ammonia (NH3) from 0.0096 to $0.0136 \mathrm{mg} / \mathrm{L}$; Nitrate (NO3) from 0.003 to $0.1593 \mathrm{mg} / \mathrm{L}$; Nitrite (NO2) 0.001 - $0.0085 \mathrm{mg} / \mathrm{L}$; Phosphate (PO4) 0.045 to $0.198 \mathrm{mg} / \mathrm{L}$; Iron (Fe) 0.035 to $0.652 \mathrm{mg} / \mathrm{L}$; and Total Suspendet Solit (TSS) 34-125 mg / L. The potential for seaweed cultivation of 17,391.87 hectares of land in accordance with the level of compliance and inappropriate 9,858.62 7,533.25 ha ha, whereas eksisiting $9,614.42$ ha of land.
\end{abstract}

Keywords : potential, land suitability, seaweed farming, Wakatobi

\section{Pendahuluan}

Kabupaten Wakatobi merupakan kabupaten kepulauan yang terletak di Provinsi Sulawsi Tenggara. Kabupaten Wakatobi memiliki luas wilayah daratan $\pm 823 \mathrm{~km} 2$ atau hanya sekitar 4,5 persen dari total wilayah Kabupaten Wakatobi secara keseluruhan, selebihnya merupakan wilayah perairan laut yang luasnya mencapai $\pm 18.377 \mathrm{~km} 2$. Kabupaten Wakatobi terdiri dari 8 wilayah kecamatan yang semuanya berada di wilayah kepulauan (43 pulau) (Anonim, 2009). Luas perairan tersebut merupakan potensi sumberdaya yang sangat potensial untuk mengembangkan berbagai kegiatan perikanan budidaya seperti budidaya rumput laut selain parawisata bahari yang telah berkembang selama ini.

Rumput laut merupakan organisma fotosintetik di laut, seperti juga halnya tumbuhan di darat. Perbedaan mendasar dari system hidupnya adalah dalam hal pengambilan zat-zat makanan (Atmadja, 1997 dalam Susanto et al, 2007). Pengembangan rumput lat di Indonesia saat ini masih terbatas pada jenis Eucheuma spp yang lebih populer dengan nama baru Kappaphycus alvarezii. Walaupun menurut Sulaeman dan Yamin (2008), jenis Gracilaria sp merupakan komoditas budidaya tambak yang juga menjadi andalan dalam revitalisasi perikanan budidaya karena memiliki nilai jual yang bak dan permintaan pasar yang terus bertambak.

Rumput laut merupakan sumber utama penghasil agar-agar, alginate dan karagenan yang dimanfaatkan dalan industry kosmetik, farmasi dan industry lainnya (industry kertas, tekstil, fotografi, pasta dan pengalengan ikan. Rumput laut memeiliki keunggulan dibandingkan dengn komoditas perikanan budidaya lainnya, antara lain; teknologi budidaya yang 
sederhana; peluang pasar ekspor yang tinggi; penyerapan tenaga kerja yang tinggi; modal yang diperlukan relative kecil; periode pemeliharaan yang singkat; produk olahan yang beragam; serta memiliki fungsi produksi dan ekologis (Parenrengi et al, 2008). Selain itu juga terdapat keunggulan lainnya yaitu pembudidaya tidak memerlukan kualifikasi ilmu tertentu sehingga dapat dilakukan oleh semua lapisan masyarakat. Menurut Parenrengi et al (2008), keunggulan-keunggulan tersebut memberikan indicator yang positif dalam upaya pengembangan usaha budidaya rumput laut.

Ragulasi pemerintah tentang komoditas unggulan yang dikembangkan dibidang perikanan budidaya menjadi pemicu utama menjamurnya pengembangan budidaya rumput laut (Kappaphycus alvarezii) di sebagian besar wilayah pesisir di Indonesia, tidak terkecuali di Kabupaten Wakatobi Provinsi Sulawesi Tenggara. Dibeberapa sentra wilayah budidaya rumput yang tersebar di pantai barat dan timur Sulawesi Selatan, telah terbukti mampu meningkatkan kesejahteraan pembudidaya dan menyerap banyak tenaga kerja. Olehnya itu peluang pengembangan budidaya rumput laut di kawasan timur Indonesia menjadi isu strategis dalam rangka meningkatkan pendapatan dan kesejahteraan masyarakat pesisir, walaupun pengembangan tersebut masih banyak menemui kendala terutama dalam hal pemilihan lokasi yang sesuai, ketersediaan bibit dan teknologi budidaya belum sepenuhnya dapat dikuasai oleh pembudidaya.

Bibit rumput laut sampai saat ini sepenuhnya masih mengandalkan bibit yang berasal dari alam. Jika kondisi tersebut berlangsung lama maka terdapat kemungkinan akan terjadi kekurangan bibit. Menurut Suryati et al (2007), teknik kultur jaringan menjanjika perbanyakan benih secara berkesinambungan dan berkualitas tinggi.

Sebagaimana daerah pesisir lainnya di Indonesia, di Kabupaten Wakatobi pada awal pengembangan budidaya belum mempertimbangkan kesesuaian lahan. Sehingga produksi yang diperoleh saat ini masih sangat memungkinkan untuk dikembangkan mengingat selain lokasi lahan budidaya yang belum tergarap masih sangat luas dan penentuan kesesuaian lahan tersebut belum ada. Menurut Utojo et al (2007), untuk kegiatan budidaya laut yang berhasil guna dan berdaya guna maka penentuan lokasi yang sesuai dengan kondisi perairan dengan jenis komoditi termasuk metode budidaya yang tepat dan ekonomis perlu menjadi perhatian yang serius.
Dalam pengembangan tersebut, pemerintah daerah dalam hal ini instansi terkait belum memiliki data potensi dan kesesuaian lahan yang akan dijadikan sebagai acuan dalam menetapkan strategi pengembangan. Kesesuaian lahan budidaya rumput laut dibangun berdasarkn data kualitas perairan. Menurut Saputra et al. (2007), untuk memastikan keberlanjutan usaha budidaya perikanan maka pengukuran dan pemantauan data kualitas perairan menjadi kunci untuk menghindarai terjadinya degradasi lingkungan. Selain itu juga bermanfaat untuk keberlanjutan usaha budidaya perikanan, karena telah diketahui bahwa kondisi kualitas perairan sangat menentukan dalam keberhasilan usaha perikanan budidaya. Selanjutnya Umar dan Jafar (2007) mempertegas bahwa kualitas fisika-kimia perairan yang baik harus didukung dengankesuburan perairan berdasarkan kandungan fitoplankton. Nybakken (1992) bahwa fitoplankton merupakan komponen utama produktifitas perairan.

Berdasarkan hal tersebut telah dilakukan penelitian yang bertujuan untuk menghitung potensi dan menentukan tingkat kesesuaian lahan budidaya rumput laut di Kabupaten Wakatobi.

\section{Metodologi}

Penelitian dilakukan dengan metode survei langsung ke lokasi penelitian untuk mengekstrak karakteristik hidro-dinamikaoseanografi yang memiliki kaitan erat dengan pertumbuhan rumput laut. Data hasil pengukuran lapangan ditabulasi dan dianalisis secara deskriptif, sedangkan analisis spasial untuk pembuatan peta tematik potensi dan sebaran kesesuaian lahan dilakukan dengan menerapkan teknologi sistem informasi geografis (SIG) memanfaatkan sofware ArcView 3.3. Bahan yang digunakan dalam penelitian ini adalah peta RBI Sulawesi lembar 2310 nomor 42,51,52, 22, 23, 24, 31 dan lembar 2309 nomor 53 dan 54.

Penelitian ini dilakukan dengan metode survei. Peralatan yang digunakan dalam penelitian ini, perahu motor, GPS, planktonet, cool box, hidrolab, layangan arus, kompas, water sampler, sechci disk, botol sampel. Sedangkan bahan kimia yang digunakan adalah pengawet logam (HNO3), pengawet air (H2SO4) dan pengawet plankton (lugol).

Krakteristik lahan budidaya dapat diketahui dengan pengambilan sampel air laut baik yang berada di dalam maupun di luar hamparan budidaya, sambil melakukan pula pengukuran insitu. Sampel air yang diambil tersebut selanjutnya dianalisis di laboratorium. 


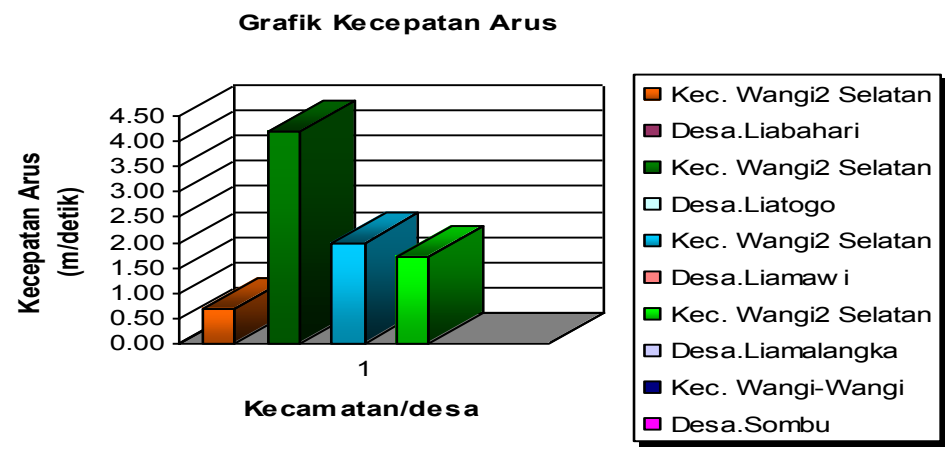

Gambar 1. Kecepatan Arus Perairan Kabupaten Wakatobi

Grafik Kecerahab

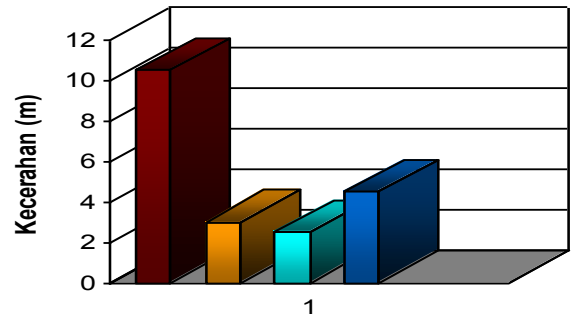

Kecam atan/Desa

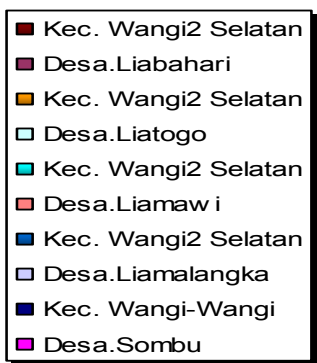

- Desa.Sombu

Gambar 2. Kecerahan Perairan Kabupaten Wakatobi

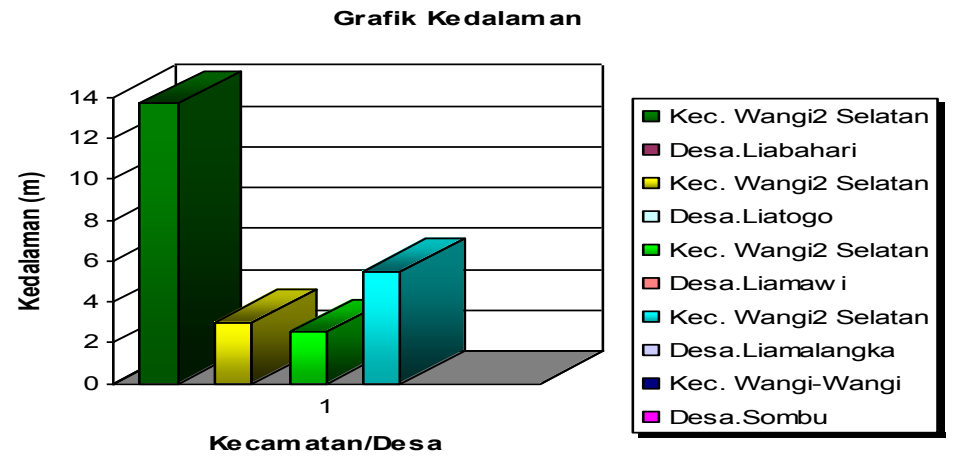

Gambar 3. Kedalaman Perairan Kabupaten Wakatobi

Hasil pengukuran insitu dan laboratorium ditabulasi dan analisis secara deskriptif. Untuk mengetahui potensi lahan budidaya rumput laut eksisting dilakukan dengan cara mengelilingi hamparan budidaya rumput laut dengan menggunakan perahu motor sambil merekam posisinya dengan menggunakan Global Potisioning Syistem (GPS), posisi tercatat dengan format UTM (Universal Transver Marcator). Posisi hasil perekaman di lapangan selanjutnya dianalisis dengan memanfaatkan sistem informasi geografis (SIG). Masih dengan analisis yang sama, dilakukan input data parameter kesesuaian lahan dalam SIG dan akan dihasilkan peta kesesuaian lahan budidaya rumput laut di perairan sekitar Kabupaten Wakatobi.

Hasil dan Pembahasan

Hidrodinamika Oseanografi

Substrad Dasar dan Arus

Kabupaten Wakatobi telah lama dikenal di Indonesia maupun mancanegara terutama karena keindahan lautnya dan merupakan salah satu kabupaten kepulauan di Indoenasi. Perairan di sekitar Kabupaten Wakatobi umumnya memiliki subsyrat pasir, karang berpasir, dan karang. Kecepatan arus saat penelitian di peraran tersebut berkisar antara 0,011-0,07 m/detik. 


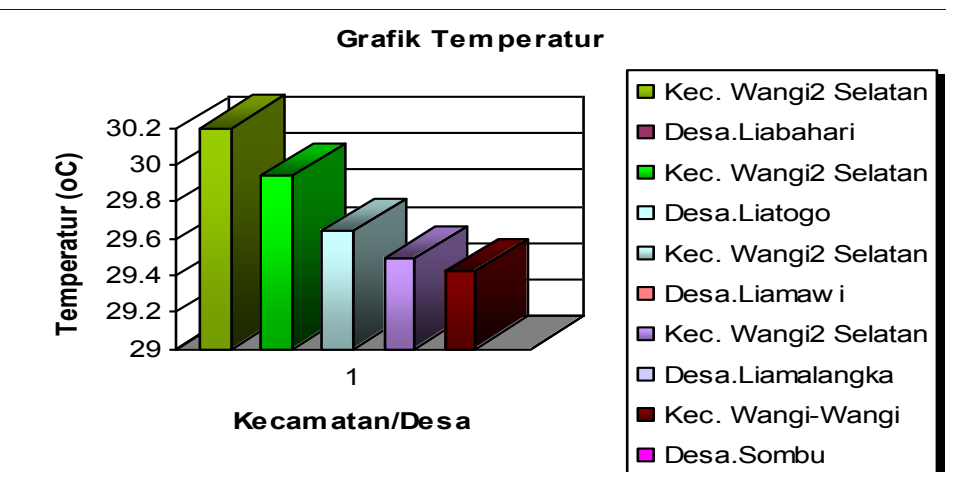

Gambar 4. Suhu Perairan Kabupaten Wakatobi

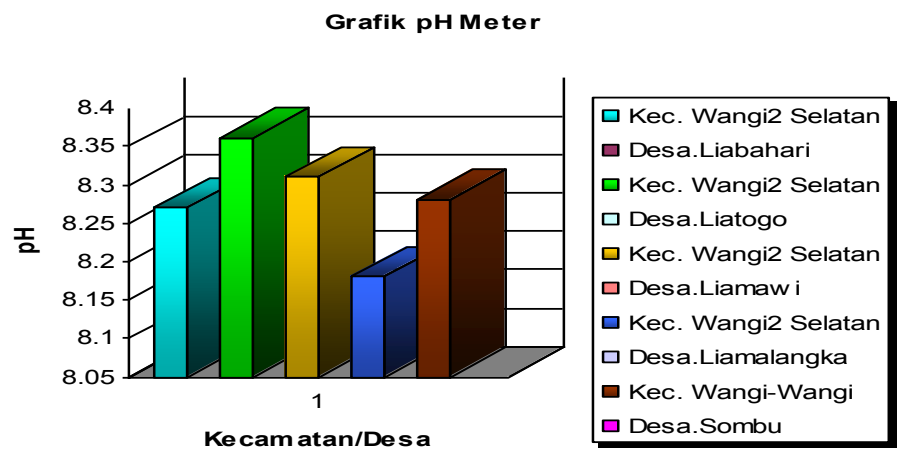

Gambar 5. pH Perairan Kabupaten Wakatobi

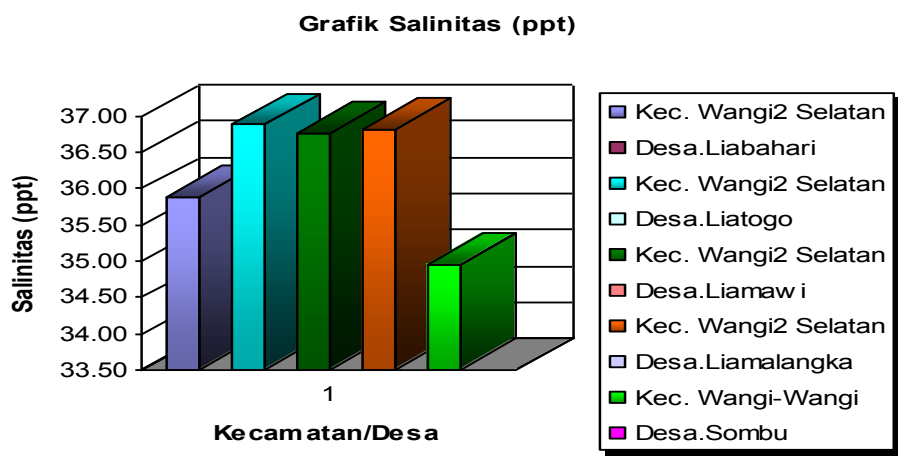

Gambar 6. Salinitas Perairan Kabupaten Wakatobi

\section{Kecerahan dan Kedalaman}

Kecerahan perairan di sekitar Kabupaten Wakatobi berkisar anatar 2,5-10,5 meter.dengan kedalam antara 2,5-13,7 meter. Dari data tersebut menunujukkan bahwa kecerahan 100\% pada kedalam 2,5 meter. Banyak faktor yang menyebabkan kecerahan pada suatu perairan, antra lain tidak adanya sungai besar yang bermuara ke laut yang membawa sedimen.

\section{Suhu, pH dan Salinitas}

Suhu perairan di sekitar Kabupaten Wakatobi berkisar antara ra $29,42-30,2^{\circ} \mathrm{C}$. Suhu air di perairan Indonesia secara makro relative, berbeda dengan suhu perairan di daerah sedang. Akibatnya suhu perairan tersebut tidak berpengaruh mematikan pada rumput laut atau hewan budidaya lainnya, demikian pula halnya dengan $\mathrm{pH}$ dan salinitas. Berdasarkan hasil pengukuran menunjukkan nilai $\mathrm{pH}$ antara 7,588,23 dan salinitas antara $34,95-36,88$ promil.

Oksigen Terlarut dan Bahan Organik Total (BOT)

Oksigen terlarut dan BOT di perairan Kabupaten Wakatobi masing-masing antara 6,06-6,25 m/L dan antara 35,52 - 42,6 mg/L. Kandungan oksigen terlarut tersebut menunjukkan bahwa di perairan tersebut tersedia cukup oksigen yang dapat 


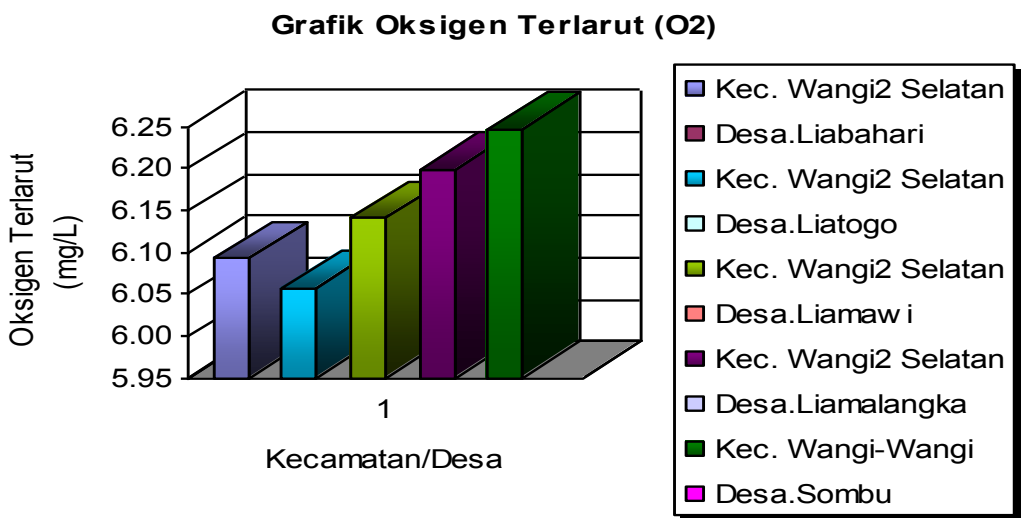

Gambar 7. Oksigen Terlarut Perairan Wakatobi

Bahan Organik Total (BOT)

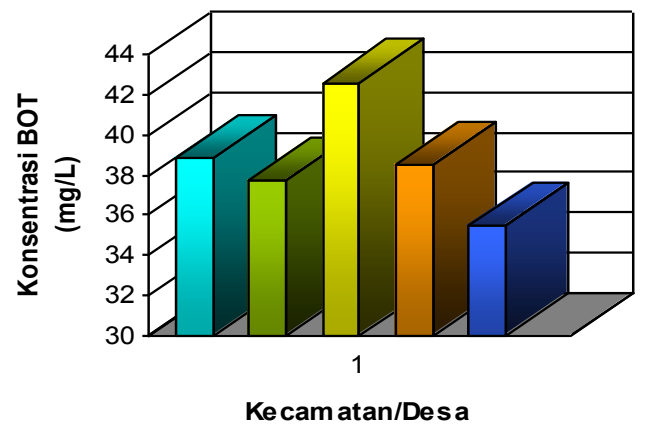

\begin{tabular}{|l|}
\hline Kec. Wangi2 Selatan \\
$\square$ Desa.Liabahari \\
$\square$ Kec. Wangi2 Selatan \\
$\square$ Desa.Liatogo \\
$\square$ Kec. Wangi2 Selatan \\
$\square$ Desa.Liamaw i \\
$\square$ Kec. Wangi2 Selatan \\
$\square$ Desa.Liamalangka \\
$\square$ Kec. Wangi-Wangi \\
$\square$ Desa.Sombu \\
\hline
\end{tabular}

Gambar 8. Kandungan Total Bahan Organik Di Perairan Kabupaten Wakatobi

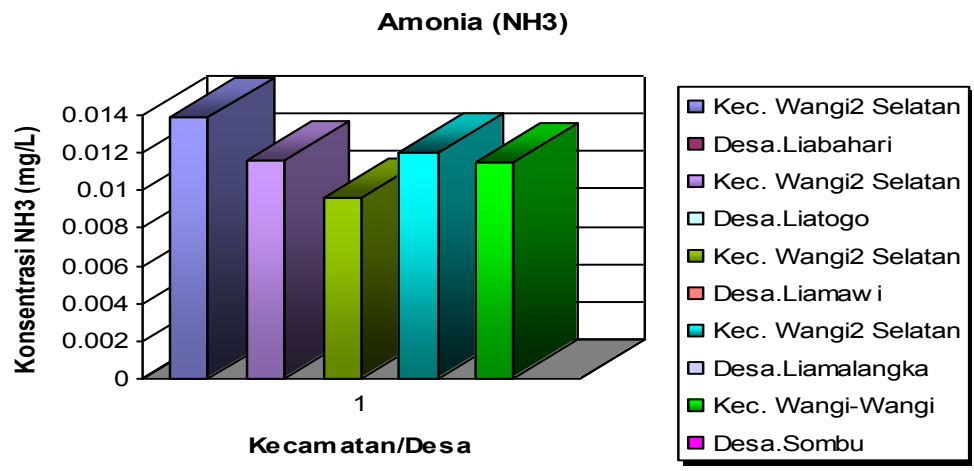

Gambar 9. Kandungan Ammonia Di Perairan Kabupaten Wakatobi

dimanfaatkan oleh organisma laut di dalamnya, sedangkan kandungan BOT tersebut menggambarkan bahwa perairan Kabupaten Wakatobi memiliki kandungan bahan organik yang cukup untuk dimanfaatkan oleh fitopklanton atau organism tingkat rendah lainnya untuk melakukan proses-proses metabolism.

Amonia $\left(\mathrm{NH}_{3}\right)$

Hasil pengukuran amonia di perairan Kabupaten Wakatobi menunjukkan konsentrasi
Ammonia $\left(\mathrm{NH}_{3}\right)$ antara 0,0096 - 0,0136 mg/L. Kandungan amonia tersebut termasuk rendah dan belum berpengaruh negatif terhadap biota laut. Amonia juga saling berhubungan dengan suhu, $\mathrm{pH}$ dan Oksigen terlarut. Semakin tinggi $\mathrm{pH}$ dan suhu maka konsentrasi amonia juga akan semakin meningkat, sedangkan pada oksigen yang tinggi maka amonia jarang didapatkan sebaliknya pada wilayah oksigen rendah kadar amonia relatif meningkat. 


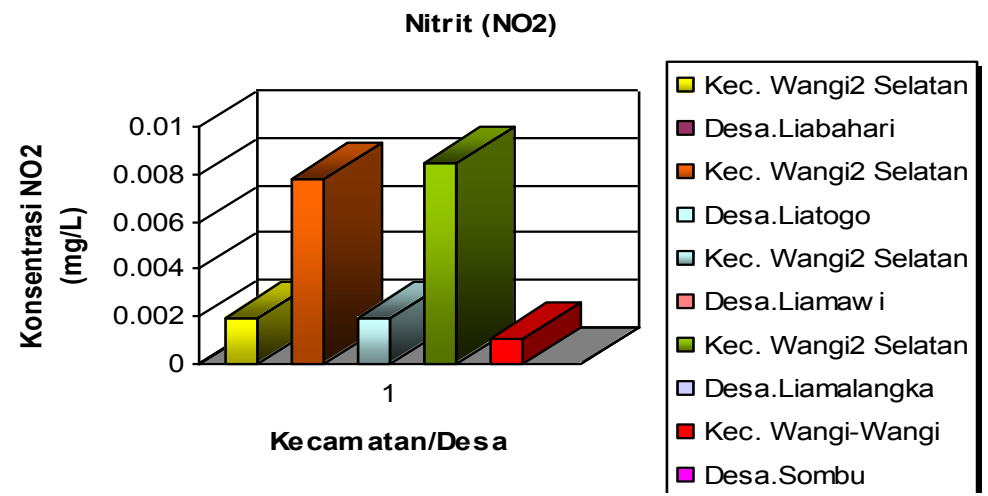

Gambar 10. Kandungan Nitrit Di Perairan Kabupaten Wakatobi

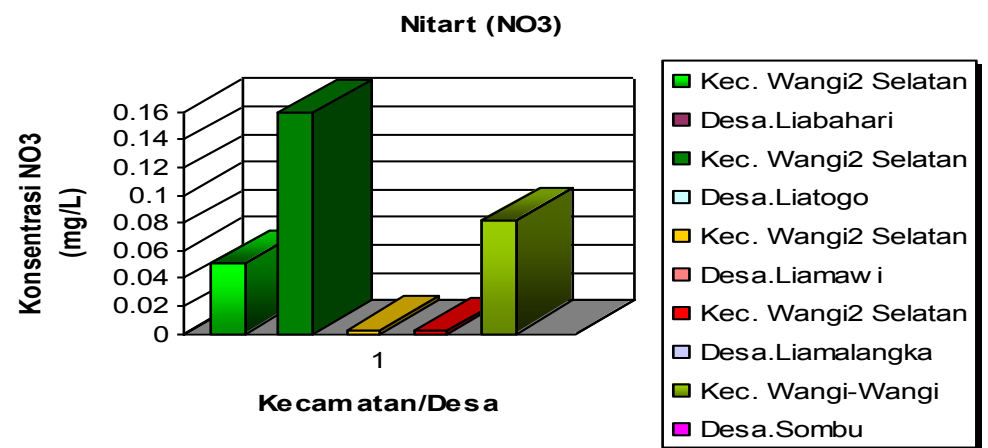

Gambar 11. Kandungan Nitrat Di Perairan Kabupaten Wakatobi

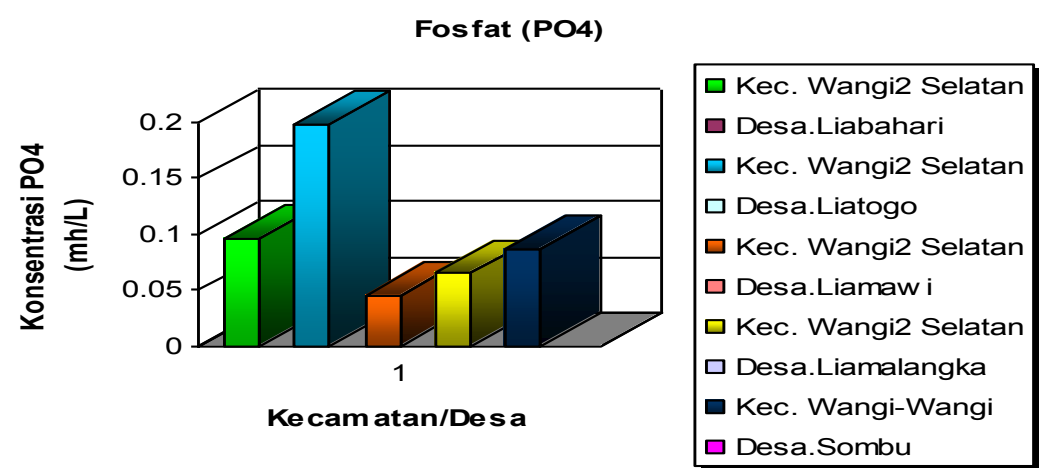

Gambar 12. Kandungan Fosfat Di Perairan Kabupaten Wakatobi

Nitrit $\left(\mathrm{NO}_{2}\right)$ dan Nitrat $\left(\mathrm{NO}_{3}\right)$

Di perairan alami, nitrit $\left(\mathrm{NO}_{2}\right)$ biasanya ditemukan dalam jumlah yang sangat sedikit, lebih sedikit daripada nitrat, karena bersifat tidak stabil dengan keberadaan oksigen. Nitrit merupakan bentuk peralihan antara amonia dan nitrat (nitrifikasi), dan antara nitrat dan gas nitrogen. Sumber nitrit dapat berupa limbah industri dan limbah domestik. Oleh karena di perairan Kabupaten Wakatobi belum tercemar limbah maka nilai nitrit yang diperoleh masih relative kecil yaitu antara $0,001-0,0085 \mathrm{mg} / \mathrm{L}$. Sama halnya dengan nitrit, nitrat karena tidak ada pencemaran maka konsentrasinya masih rendah yaitu antara $0,003-0,1593 \mathrm{mg} / \mathrm{L}$
Fosfat $\left(\mathrm{PO}_{4}\right)$, Besi dan Total Suspendet Solit (TSS)

Konsentrasi fosfor $\left(\mathrm{PO}_{4}\right)$ di perairan Wakatobi anatara 0,045 - 0,198 mg/L. Fosfor dapat menjadi faktor pembatas terhadap biomassa dan produksi gel rumput laut. Data tersebut menunjukkan bahwa fosfat di perairan Kabupaten Wakatobi masih cukup untuk pertumbuhan biota laut. Demikian pula dengan konsentrasi besi di perairan Kabupaten Wakatobi masih aman untuk biota laut terutama tumbuhan tingkat rendah seperti fitopklanton dan rumput laut dengan kadar antara 0,035 $0,652 \mathrm{mg} / \mathrm{L}$. edangkan TSS konsentrasinya mencapai antara $34-125 \mathrm{mg} / \mathrm{L}$ 


\section{Besi (Fe)}

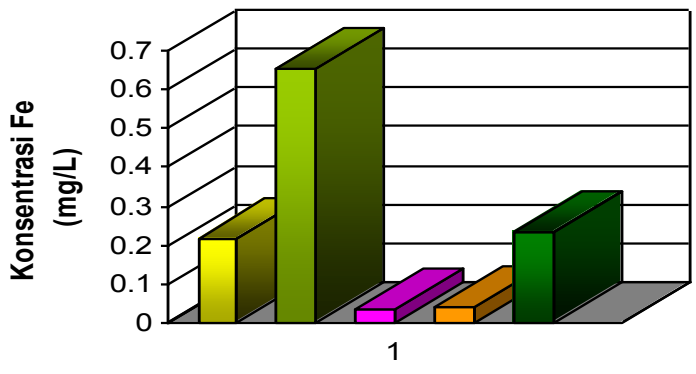

Ke cam atan/Des a

\begin{tabular}{|l|}
\hline$\square$ Kec. Wangi2 Selatan \\
$\square$ Desa.Liabahari \\
$\square$ Kec. Wangi2 Selatan \\
$\square$ Desa.Liatogo \\
$\square$ Kec. Wangi2 Selatan \\
$\square$ Desa.Liamaw i \\
$\square$ Kec. Wangi2 Selatan \\
$\square$ Desa.Liamalangka \\
$\square$ Kec. Wangi-Wangi \\
$\square$ Desa.Sombu
\end{tabular}

Gambar 13. Kandungan Besi Di Perairan Wakatobi

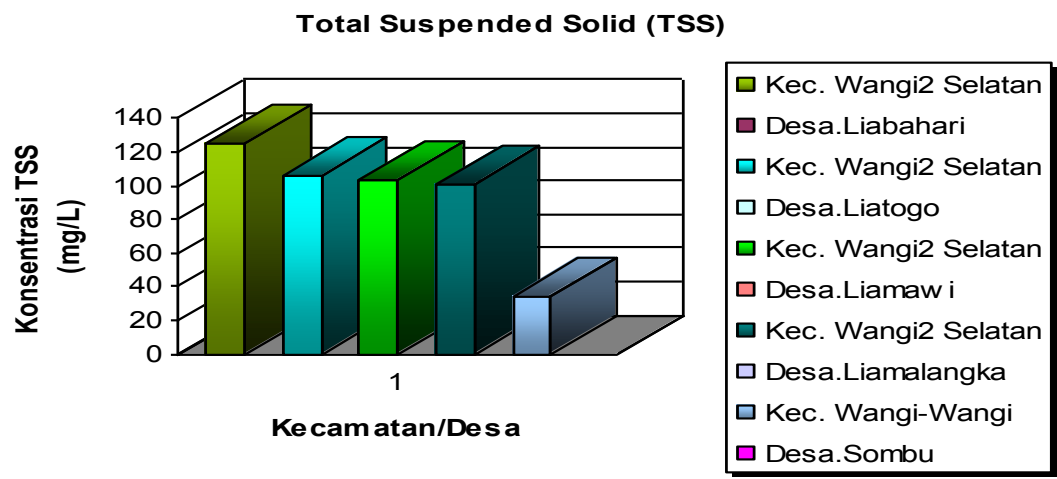

Gambar 14. Kandungan Total Bahan Organik Di Perairan Kabupaten Wakatobi

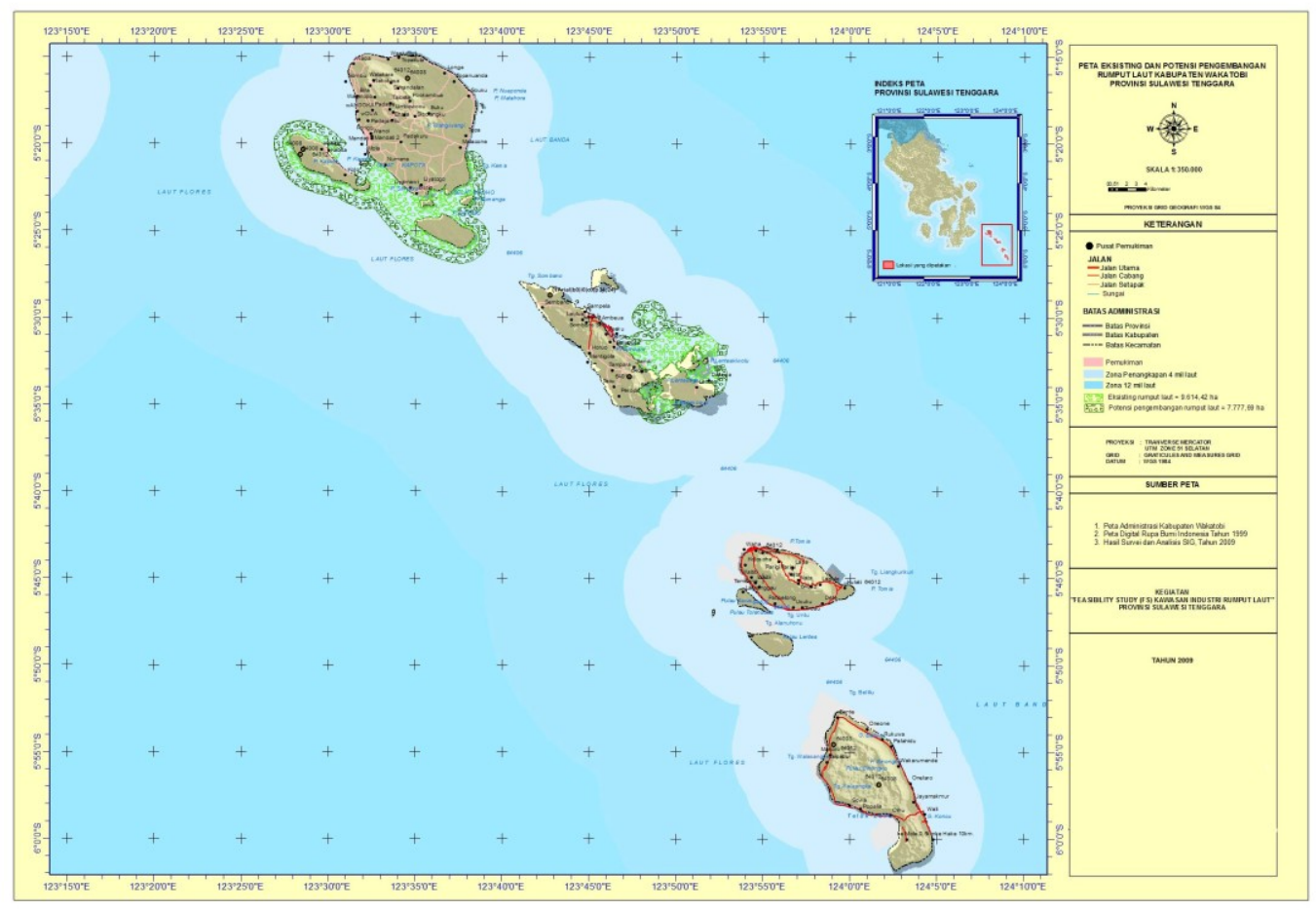

Gambar 15. Peta Potensi Pengembangan Rumput Laut Di Kab. Wakatobi 


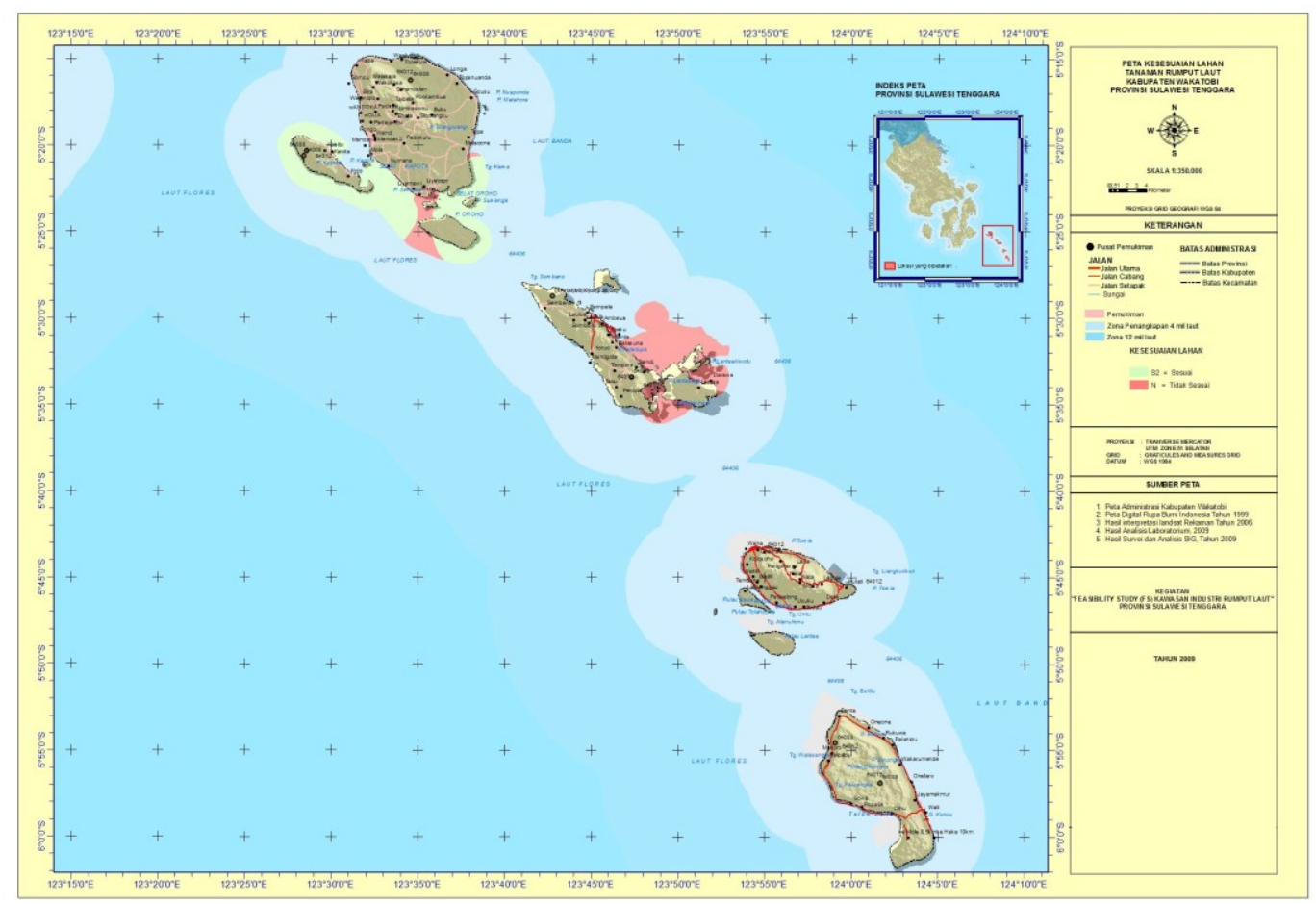

Gambar 16. Peta Kesesuaian Lahan Budidaya Rumput Laut Di Kabupaten Wakatobi

Potensi Dan Kesesuaian Lahan

Potensi

Berdasarkan analisis yang dilakukan menunjukkan bahwa potensi areal pengembangan rumput laut di Kabupaten Wakatobi mencapai 17,391.87 ha, sementara itu daerah tergarap masih sangat rendah baru mencapai kurang lebih 1000 ha. Dengan demikian masih terdapat kemungkinan untuk meningkatkan produksi.

Kesesuaian Lahan

Dari luas lahan 17,391.87 yang berpotensi untuk dikembangkan menjadi areal budidaya rumput laut terdapat $9,858.62$ ha yang sesuai dan sisanya 7,533.25 ha tidak sesuai. Tidak sesuai tersebut lebih banyak disebabkan oleh areal yang tersedia masuk dalam kawasan lindung.

\section{Kesimpulan}

Kondisi hidro-oseanografi perairan Kabupaten Wakatobi masih tergolong alami (belum tercemar) dan memungkinkan untuk mengembangkan usaha budidaya rumput laut. Potensi areal budidaya di perairan Kabupaten wakatobi mencapai 17,391.87 ha yang tergolong sesuai seluas 9,858.62 ha. Perlu dilakukan penelitian kalender musim (musim tanam) untuk mengetahui waktu dimana dapat dilakukan budidaya secara optimal.

\section{Daftar Pustaka}

Anonim, 2009. Kabupaten Wakatobi dalam angka Badan Perencanaan Pembangunan, Penanaman Modal, Penelitian dan Pengembangan Daerah dan Badan Pusat Statistik Kabupaten Wakatobi. 252 hal.

Nybakken, J.W., 1992. Biologi Laut. Suatu pendekatan ekologis. PT. Gramedia Pustaka Utama. Jakarta.

Parenrengi, A., Rachmansyah dan Suryati, E., 2008. Budidaya rumput laut berkelanjutan dengan dukungan teknologi penyediaan benih secara in vitro. Teknologi Perikanan Budidaya. Pusat Riset Perikanan Budidaya. Jakarta. Hal 25-38.

Saputra, A., Radiarta, I.N., Prihadi, T.H., Priono, B., dan Kusrini, E., 2007. Kajian kualitas air Teluk Kapontori untuk mendukung perikanan budidaya yang berkelanjutan dan ramah lingkungan. Prosiding Pengembangan Teknologi Budidaya Perikanan. Badan Riset Kelautan dan Perikanan. Jakarta. 132-136. 
Sulaeman dan Yamin, M., 2008. Polikultur kepiting bakau (Scylla paramamossain) dan rumput laut (Gracilaria verrucosa) di Tambak. Teknologi Perikanan Budidaya. Pusat Riset Perikanan Budidaya. Jakarta. Hal 193-198.

Susanto, AB., Limantara, L., dan Pangestuti, R. 2007. Prospek pengembangan rumput laut di Indonesia. Prosiding Pengembangan Teknologi Budidaya Perikanan. Badan Riset Kelautan dan Perikanan. Jakarta. Hal 7-19.

Suryati, E., Tenriulo, A., dan Rezeki, S., 2007. Isolasi protoplas rumput laut (Kappaphycus alvarevii) menggunakan enzyme komersial dan viscera mas (Pila polita). Prosiding Pengembangan Teknologi Budidaya Perikanan. Badan Riset Kelautan dan Perikanan. Jakarta. 132-136.
Umar, J.M., dan Jafar, S., 2007. Tingkat kesuburan perairan di Pantai Paradiso Kota Kupang ditinjau dari komposisi, kelimpahan dan keanekaragaman fitoplankton. Prosiding Pengembangan Teknologi Budidaya Perikanan. Badan Riset Kelautan dan Perikanan. Jakarta. 211-215.

Utojo, Mansyur, A., Tangko, A.M., Hasnawi dan Mulia, T., 2007. Pemilihan lokasi budidaya ikan, rumput laut, dan kerang mutiara yang ramah lingkungan di Teluk Tomini Sulawesi Tengah. Prosiding Pengembangan Teknologi Budidaya Perikanan. Badan Riset Kelautan dan Perikanan. Jakarta. 200210. 